\title{
Simultaneous Quantitative Analysis of EO9 (Apaziquone) and its Conversion Products EO5a and EO9-Cl in Human and Dog Urine by High-Performance Liquid Chromatography Coupled with Electrospray Tandem Mass Spectrometry
}

\author{
Liia D. Vainchtein ${ }^{*}, 1$, Hilde Rosing ${ }^{2}$, Dorla Mirejovsky ${ }^{3}$, Van Huynh $^{3}$, Luigi Lenaz ${ }^{3}$, \\ Jan H.M. Schellens ${ }^{4,5}$ and Jos H. Beijnen ${ }^{*, 2,4,5}$
}

\author{
${ }^{1}$ Astellas Pharma Europe B.V., Exploratory Development Department, Elisabethhof 1, 2353 EW Leiderdorp, P.O. Box \\ 108, 2350 AC Leiderdorp, The Netherlands \\ ${ }^{2}$ Department of Pharmacy \& Pharmacology, Slotervaart Hospital / The Netherlands Cancer Institute, Louwesweg 6, \\ 1066 EC Amsterdam, The Netherlands \\ ${ }^{3}$ Spectrum Pharmaceuticals, Inc, 157 Technology Drive, Irvine, CA 92618, USA \\ ${ }^{4}$ Division of Drug Toxicology, Department of Biomedical Analysis, Faculty of Pharmaceutical Sciences, Utrecht Univer- \\ sity, P.O. Box 80082, 3508 TB Utrecht, The Netherlands \\ ${ }^{5}$ Department of Medical Oncology, Antoni van Leeuwenhoek Hospital / The Netherlands Cancer Institute, Plesmanlaan \\ 121, 1066 CX Amsterdam, The Netherlands
}

\begin{abstract}
A sensitive and specific LC-MS/MS assay for the quantitative determination of anticancer agent EO9 and its conversion products EO5a and EO9-Cl in human and dog urine is presented. A $20-\mu \mathrm{L}$-urine aliquot was spiked with a mixture of deuterated internal standards EO9-d3 and EO5a-d4 and diluted with $180 \mu \mathrm{L} 0.1 \mathrm{M}$ ammonium acetate methanol (7:3, v/v). Next, $25 \mu \mathrm{L}$-volumes were injected onto the HPLC system. Separation was achieved on a $150 \times 2.1$ mm C18 column using an alkaline eluent ( $1 \mathrm{mM}$ ammonium hydroxide - methanol (gradient system)). Detection was executed by positive ion electrospray followed by tandem mass spectrometry. The assay quantifies a range from 0.1 $\mu \mathrm{g} / \mathrm{mL}$ to $50 \mu \mathrm{g} / \mathrm{mL}$ for EO9, from $0.2 \mu \mathrm{g} / \mathrm{mL}$ to $50 \mu \mathrm{g} / \mathrm{mL}$ for EO5a and $0.1 \mu \mathrm{g} / \mathrm{mL}$ to $4 \mu \mathrm{g} / \mathrm{mL}$ for EO9-Cl using $20 \mu \mathrm{L}$ of stabilized urine samples. Validation results demonstrate that EO9, EO5a and EO9-Cl concentrations can be accurately and precisely quantified in human and dog urine. This assay is used now to support pre-clinical and clinical pharmacologic studies with intravesically administered EO9.
\end{abstract}

Keywords: Indoloquinones, bioreductive anticancer drugs, intravesical route, bladder cancer, DNA adducts.

\section{INTRODUCTION}

The indoloquinone compound apaziquone (3-hydroxy-5aziridinyl-1-methyl-2[indole-4,7-dione]-prop- $\beta$-en- $\alpha$-ol; EO9, see Fig. (1) for structure) is a bioreductive anticancer drug that was selected for clinical evaluation on the basis of a novel mechanism of action and good preclinical anti-tumor activity [1-3].

EO9 is an inactive pro-drug that undergoes redox cycling leading to the formation of drug-derived DNA alkylating moieties or DNA-damaging reactive oxygen species. These alkylating intermediate species are capable of forming DNA adducts with single - strand breaks and DNA cross-linking and leading to cell kill $[4,5]$.

\footnotetext{
*Address correspondence to these authors at the Astellas Pharma Europe B.V., Exploratory Development Department, Elisabethhof 1, 2353 EW Leiderdorp, P.O. Box 108, 2350 AC Leiderdorp, The Netherlands; Tel. +31-71-545 5810; Fax: +31-71-545 5219; E-mail: liia.vainchtein@eu.astellas.com and Division of Drug Toxicology, Department of Biomedical Analysis, Faculty of Pharmaceutical Sciences, Utrecht University, P.O. Box 80082, 3508 TB Utrecht, The Netherlands; Tel: +31-30-2537305; E-mail: apjby@slz.nl
}

EO9 is extensively metabolized. One of the principal known metabolites/degradation products is EO5a, which has an open aziridine ring and shows less cytotoxicity than EO9. Another degradation product, which was discovered by us and described earlier, is EO9 with covalently attached chlorine $(\mathrm{EO} 9-\mathrm{Cl})$. It is formed in the acid-catalyzed reaction of EO9 in the presence of chloride anions in urine [6, 7].

EO9 has a very short half-life in plasma ( $\mathrm{t}_{1 / 2}$ values ranging from 0.8 to $19 \mathrm{~min}$ in humans) and a relatively poor ability to penetrate through multicell layers in vitro. However, this is an advantage for chemotherapeutic treatment of cancers that arise in a delimited compartment, such as superficial bladder cancer $[8,9]$. In this case, drug delivery can be accomplished via the intravesical route and drug exposure of tumor tissue can be maintained with therapeutically relevant drug concentrations within the bladder cavity $[8,9]$. Consequently, currently ongoing clinical trials investigating EO9 in superficial bladder tumors with local drug delivery show promising response rates. Drug analysis in voided urine provides insight into the pharmacologic behavior of EO9 after intravesical administration [10-14]. 
A

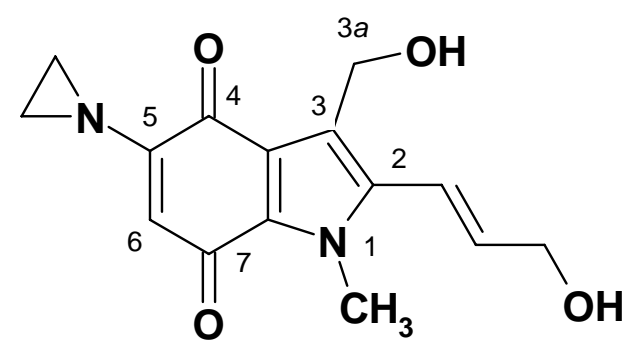

B<smiles>Cn1c(/C=C/CO)c(CO)c2c1C(=O)C=C(N1CC1)C2=O</smiles>

C<smiles>Cn1c(/C=C/CO)c(CO)c2c1C(=O)C=C(NCCO)C2=O</smiles>

D<smiles>[2H]C([2H])(O)C([2H])([2H])NC1=CC(=O)c2c(c(CO)c(/C=C/CO)n2C)C1=O</smiles>

E<smiles>Cn1c(/C=C/CO)c(CO)c2c1C(=O)C=C(NCCCl)C2=O</smiles>

Fig. (1). Chemical structures of EO9, EO9-d3, EO5a, EO5a-d4 and EO9-Cl.

So far, however, cnly one analytical assay has been published describing the determination of EO9 and EO5a, but not $\mathrm{EO} 9-\mathrm{Cl}$, in human urine using high-performance liquid chromatography coupled to the ultraviolet detection with low specificity [15]. We have published earlier a high performance liquid chromatography coupled to tandem mass spec- trometry method (HPLC-MS/MS) method for the analysis of EO9 and EO5a in human plasma [16]. This assay was, however, not suitable for urine analysis. In order to quantify all three compounds of interest, $\mathrm{EO} 9, \mathrm{EO} 5 \mathrm{a}$ and $\mathrm{EO} 9-\mathrm{Cl}$ in ongoing and upcoming preclinical and clinical studies, we developed a sensitive, specific, accurate, and rapid assay for the quantification of these analytes in human and dog urine using an HPLC-MS/MS. Deuterated internal standards for EO9 and EO5a were used for quantification. The method has been fully validated according to the FDA guidelines on bioanalytical validation $[17,18]$, and will be applied in the pharmacokinetic studies with intravesically administered EO9.

\section{EXPERIMENTAL}

\subsection{Materials}

EO9 $\left(\mathrm{C}_{15} \mathrm{H}_{16} \mathrm{~N}_{2} \mathrm{O}_{4}\right), \quad$ EO9-d3 internal standard $\left(\mathrm{C}_{15} \mathrm{H}_{13} \mathrm{D}_{3} \mathrm{~N}_{2} \mathrm{O}_{4}\right)$, EO5a $\left(\mathrm{C}_{15} \mathrm{H}_{18} \mathrm{~N}_{2} \mathrm{O}_{5}\right)$, EO5a-d4 internal standard $\left(\mathrm{C}_{15} \mathrm{H}_{14} \mathrm{D}_{4} \mathrm{~N}_{2} \mathrm{O}_{5}\right)$ and the degradation product EO9$\mathrm{Cl}\left(\mathrm{C}_{15} \mathrm{H}_{17} \mathrm{~N}_{2} \mathrm{O}_{4} \mathrm{Cl}\right)$ (see Fig. (1) for structures) were supplied by Spectrum Pharmaceuticals, Inc (Irvine, CA, USA). Methanol (LC gradient grade) was from Bissolve Ltd. (Amsterdam, The Netherlands). All other solvents or chemicals were analytical grade or better. Distilled water was used throughout the analyses. Drug free human urine was obtained from volunteers from the laboratory of the Department of Pharmacy \& Pharmacology at the Slotervaart Hospital (Amsterdam, The Netherlands). Drug free dog urine was obtained from MPI research (Mattawan, MI, USA)

\subsection{Preparation of Stock and Working Solutions}

Two sets of stock solutions of EO9, EO5a and EO9-Cl were prepared from two independent weighings and dissolution in ethanol at a target concentration of $1 \mathrm{mg} / \mathrm{mL}$. The solutions had to be placed in the ultrasonic bath for 2 hours to dissolve all the compounds in ethanol. The same procedure was repeated each time the solutions were taken out of the freezer. These solutions were further diluted with ethanol to yield separate working solutions for EO9, EO5a and EO9$\mathrm{Cl}$. One set of each working solutions was used to prepare calibration standards, the other to prepare quality control samples. The obtained concentrations of calibration standards working solutions were $800,400,200,40,20,4$ and 2 $\mu \mathrm{g} / \mathrm{mL}$ for EO9; 800, 400, 200, 40, 20, 10 and $4 \mu \mathrm{g} / \mathrm{mL}$ for EO5a and 400, 100, 80, 60, 40, 30, 20, 10, 4 and $2 \mu \mathrm{g} / \mathrm{mL}$ for EO9-Cl. The quality control working solutions concentrations were 800, 200, 6 and $2 \mu \mathrm{g} / \mathrm{mL}$ for EO9; 800, 200, 12 and $4 \mu \mathrm{g} / \mathrm{mL}$ for EO5a and $60,40,20,6$ and $2 \mu \mathrm{g} / \mathrm{mL}$ for EO9-Cl. Separate stock solutions of EO9-d3 and EO5a-d4 were prepared in ethanol at a concentration of $1 \mathrm{mg} / \mathrm{mL}$. An internal standards working solution was prepared by transferring $500 \mu \mathrm{L}$ of EO9-d3 stock solution and $500 \mu \mathrm{L}$ of EO5a-d4 stock solution to a $50.0 \mathrm{~mL}$ volumetric flask and adding $0.1 \mathrm{M}$ ammonium acetate buffer $\mathrm{pH} 8.5$ - methanol $(7: 3, \mathrm{v} / \mathrm{v})$ to give a final concentration of $10,000 \mathrm{ng} / \mathrm{mL}$ for both internal standards. All solutions were stored at $-20^{\circ} \mathrm{C}$.

\subsection{Preparation of Control Human and Dog Stabilized Urine}

The formulated product of EO9 (EOquin $^{\mathrm{TM}}$ ) is used in clinical studies. This formulation consisted of $4 \mathrm{mg}$ of EO9, $25 \mathrm{mg}$ mannitol, $10 \mathrm{mg}$ sodium bicarbonate and $40 \mathrm{~mL}$ of the 
diluent. The diluent formulation contained $10 \mathrm{mg} / \mathrm{mL}$ sodium bicarbonate (20 mg/mL for dogs), $0.2 \mathrm{mg} / \mathrm{mL}$ EDTA, and 0.6 $\mathrm{mL}$ propylene glycol in sterile water for injection (SWFI). The average volume collected after 60 min of instillation was $120 \pm 47 \mathrm{~mL}$, which consisted of EOquin formulation solution - human urine $(1: 2, \mathrm{v} / \mathrm{v})$ [15]. In dogs however, the total collected urine was approximately $80 \mathrm{~mL}$, which consisted of EOquin formulation solution - dog urine $(1: 1, v / v)$. After the collection of samples, an equal volume of TRIS buffer $(5 \mathrm{mM}$; $\mathrm{pH}$ 9.0) was added to raise the $\mathrm{pH}$ of urine and therefore prevent ex vivo degradation (stabilization of urine).

EO9 is most stable at approximately $\mathrm{pH}$ 8.5. To mimic the in vivo situation, we prepared the stabilized control human urine solutions, which consisted of $100 \mathrm{~mL}$ blank formulation $(0.525 \mathrm{~g}$ sodium bicarbonate, $0.01 \mathrm{~g}$ EDTA, 62.5 $\mathrm{mg}$ mannitol, $30 \mathrm{~mL}$ propylene glycol in $70 \mathrm{~mL} \mathrm{SWFI}), 200$ $\mathrm{mL}$ control human urine and $300 \mathrm{~mL}$ TRIS buffer $(5 \mathrm{mM}$; $\mathrm{pH}$ 9.0). The stabilized control dog urine solution consisted of $100 \mathrm{~mL}$ blank formulation (1.03 g sodium bicarbonate, 0.01 g EDTA, $62.5 \mathrm{mg}$ mannitol, $30 \mathrm{~mL}$ propylene glycol in 70 $\mathrm{mL}$ SWFI), $100 \mathrm{~mL}$ control dog urine and $200 \mathrm{~mL}$ TRIS buffer (5mM; pH 9.0).

\subsection{Preparation of Calibration Standards and Quality Control Samples in Stabilized Human and Dog Urine}

Calibration standards containing EO9, EO5a and EO9-Cl were prepared freshly in a range from $0.1 \mu \mathrm{g} / \mathrm{mL}$ to $50 \mu \mathrm{g} / \mathrm{mL}$ for EO9, from $0.2 \mu \mathrm{g} / \mathrm{mL}$ to $50 \mu \mathrm{g} / \mathrm{mL}$ for EO5a and 0.1 $\mu \mathrm{g} / \mathrm{mL}$ to $4 \mu \mathrm{g} / \mathrm{mL}$ for EO9-Cl by adding $25 \mu \mathrm{L}$ of EO9, EO5a and EO9-Cl working solutions in ethanol (described in section 2.2 ) to $2 \mathrm{~mL}$-Eppendorf tubes. This solutions were evaporated and the compounds were redissolved in stabilized human urine and stabilized dog urine, respectively, to yield concentrations of $0.1,0.2,1.0,2.0,10,20,40$ and $50 \mu \mathrm{g} / \mathrm{mL}$ for EO9; 0.2 , $0.5,1.0,2.0,10,20,40$ and $50 \mu \mathrm{g} / \mathrm{mL}$ for EO5a, and 0.1, 0.2, $0.5,1.0,1.5,2.0,3.0$ and $4.0 \mu \mathrm{g} / \mathrm{mL}$ for $\mathrm{EO} 9-\mathrm{Cl}$ in human and dog urine. The calibration standards were vortex-mixed for approximately $30 \mathrm{sec}$ before processing. Standards were processed in singlicate and analyzed in duplicate.

Quality control samples for EO9, EO5a and EO9-Cl were prepared in stabilized human respectively dog urine at concentrations of $0.1,0.3,10$ and $40 \mu \mathrm{g} / \mathrm{mL}$ for EO9; 0.2, 0.6, 10 and $40 \mu \mathrm{g} / \mathrm{mL}$ for EO5a, and 0.1, 0.2, 2.0 and $3.0 \mu \mathrm{g} / \mathrm{mL}$ for EO9-Cl using the same procedure as described above for the calibration standards. The calibration standards and quality control samples were prepared fresh for each validation run.

\subsection{Sample Preparation}

Sample pretreatment was performed at ambient temperatures. $20 \mu \mathrm{L}$ of a working solution containing the internal standards was added to $20 \mu \mathrm{L}$ of stabilized human or dog urine aliquots and diluted with $180 \mu \mathrm{L} 0.1 \mathrm{M}$ ammonium acetate buffer $\mathrm{pH} 8.5$ - methanol (7:3, v/v). The samples were vortexed for $10 \mathrm{sec}$ and the clean solution was transferred to a glass autosampler vial with insert.

\subsection{HPLC}

The HPLC system comprises an HP1100 binary pump, degasser and HP1100 autosampler (Agilent Technologies, Palo Alto, CA). Gradient chromatography was performed using a Gemini C18 column $(150 \times 2.1 \mathrm{~mm}$ ID, particle size
$5 \mu \mathrm{m})$. The mobile phase consisted of $1 \mathrm{mM}$ ammonium hydroxide in water (A) and $100 \%$ methanol (B) and was pumped at a flow-rate of $0.2 \mathrm{~mL} / \mathrm{min}$. In the first $0.3 \mathrm{~min}$, the eluent consisted of $60 \% \mathrm{~A}$ and $40 \% \mathrm{~B}$, followed by $90 \% \mathrm{~B}$ for $2.7 \mathrm{~min}$. To stabilize the column, $40 \% \mathrm{~B}$ was used for 2 min. Sample injections of $25 \mu \mathrm{L}$ were carried out and the autosampler temperature was kept at $10^{\circ} \mathrm{C}$.

\subsection{Mass Spectrometry}

The LC eluate was directed into an API 2000 triple quadrupole MS equipped with an electrospray (ESI) ion source (Sciex, Thornhill, ON, Canada) [16]. Positive ions were created at atmospheric pressure and the mass analyzer was operated in the multiple reaction monitoring (MRM) mode using unit resolution for the quadrupoles. The resulting MRM chromatograms were used for quantification utilizing Analyst $^{\mathrm{TM}}$ software version 1.2 (Sciex). Mass transitions of $\mathrm{m} / \mathrm{z}$ $271 \rightarrow 241,274 \rightarrow 244,307 \rightarrow 231,311 \rightarrow 231,325 \rightarrow 241$ were optimized for EO9, EO9-d3, EO5a, EO5a-d4 and EO9$\mathrm{Cl}$, respectively, with dwell times of $150 \mathrm{~ms}$. EO9-d3 was used as an internal standard for EO9 and EO9-Cl. EO5a-d4 was used to quantify EO5a. Nebulizer gas (compressed air), turbo gas (compressed air), curtain gas $\left(\mathrm{N}_{2}\right)$, and collision activated dissociation gas $\left(\mathrm{N}_{2}\right)$ were operated at 40, 65, 20, and 4 psi, respectively. Furthermore, declustering potential (DP) for EO9 and EO9-d3 was $66 \mathrm{~V}$ and for EO5a, EO9-Cl and EO5a-d4 was $31 \mathrm{~V}$. Focusing potential (FP) for EO9 and EO9-d3 was $310 \mathrm{~V}$ and for EO5a, EO9-Cl and EO5a-d4 was $350 \mathrm{~V}$. The optimized collision energy (CE) was $17 \mathrm{~V}$ for EO9 and EO9-d3, $45 \mathrm{~V}$ for EO5a and EO5a-d4 and $40 \mathrm{~V}$ for EO9-Cl. Finally, the ion spray voltage was kept at $5500 \mathrm{~V}$, with a source temperature of $250^{\circ} \mathrm{C}$.

\subsection{Validation Procedures}

A full validation programme according to the FDA guidelines was performed for the assay in human urine [17, 18]. For the assay in dog urine partial validation was executed by means of accuracy and precision, specificity and selectivity and stability in urine under storage conditions according to FDA rules.

\subsubsection{Linearity}

For the validation of the assay in human urine, calibration standards (8 non-zero standards of the analytes) were prepared in stabilized control human urine and analyzed in duplicate in three analytical runs. For the validation of the assay in dog urine, calibration standards (8 non-zero standards of the analytes) were prepared in stabilized control dog urine and analyzed in duplicate in one analytical run.

The linear regression of the ratio of the areas of the analyte and internal standard peaks versus the concentration were weighed by $1 / \mathrm{x}^{2}$ (the reciprocal of the squared concentration). Concentrations were back-calculated from the constructed calibration curve and deviations from the nominal concentrations should be within $\pm 20 \%$ for the lower limit of quantitation (LLOQ) and within $\pm 15 \%$ for other concentrations with coefficient of variation (C.V.) values less than $20 \%$ and $15 \%$ respectively [19].

\subsubsection{Accuracy and Precision}

Five replicates of the quality control samples (see section 2.4) were analyzed in each analytical run together with the 
calibration standards. Accuracies were determined as the percentage difference of the measured concentration from the nominal concentration and the C.V. was used to report the precision.

The intra and inter-assay accuracies (\% bias) should be within $\pm 20 \%$ at the LLOQ level and within $\pm 15 \%$ at the other concentrations. The intra and inter-assay precisions should be less than $20 \%$ at the LLOQ level and less than $15 \%$ at the other concentrations.

The ability to dilute samples originally above the upper limit of quantitation (ULOQ) of the calibration curve was demonstrated by and analyzing validation samples containing 5 times the ULOQ for EO9, EO5a and EO9-Cl. Five replicates of each sample were analyzed in one analytical run after 20 time dilution in stabilized control human and control dog urine.

\subsubsection{Limit of Detection}

The limit of detection (LOD) for EO9, EO5a and EO9$\mathrm{Cl}$, with the responses of the analytes at 2 times the response of the blank was established in three analytical runs in human urine.

\subsubsection{Specificity and Selectivity}

To investigate whether endogenous matrix constituents interfered with the assay, six individual batches of control drug-free human and dog urine samples containing neither analyte nor internal standard (double blank), samples containing only internal standard (blank), and samples spiked at the LLOQ were prepared. Samples were prepared and analyzed according to the described procedures. Peak areas of compounds co-eluting with the analyte or internal standard should not exceed $20 \%$ of the analyte peak area at the LLOQ or $5 \%$ of the internal standard area. Deviations from the nominal concentrations should be within $\pm 20 \%$ for the LLOQ samples.

\subsubsection{Ion Suppression}

Ion suppression was determined by comparing the analytical response of processed quality control samples with the analytical response of blank samples reconstituted with solutions containing the analytes and internal standards in $0.1 \mathrm{M}$ ammonium acetate $\mathrm{pH} 8.5$ - methanol (7:3, v/v). The loss of signal represents the ion-suppression. These experiments were performed in triplicate at three concentration levels. Ion suppression experiments for the internal standards were performed in a similar way [20].

\subsubsection{Carry-Over}

Carry-over was tested by injecting two blank matrix samples after injecting an ULOQ sample. Carry-over is considered acceptable when response in the first blank matrix at the retention times of the analytes are less than $20 \%$ of the response in an LLOQ samples.

\subsubsection{Stability}

To test the stability of EO9, EO5a and EO9-Cl during processing at the clinical sites, the stability of analytes was evaluated in the non-stabilized control human urine maintained on an ice/water bath. The stability of analytes in stabilized human and dog urine after 3 freeze/thaw cycles was investigated by comparing quality control samples that had been frozen and thawed three times with freshly prepared quality control samples. The stability of EO9, EO5a and EO9- $\mathrm{Cl}$ in human and dog urine under processing (ambient temperatures) and storage $\left(-70^{\circ} \mathrm{C}\right)$ conditions was evaluated. Furthermore, the stability in the final solution and the reinjection reproducibility in the auto sampler was determined after 24h. Finally, the long-term stability of EO9, EO5a and EO9-Cl was evaluated in the stock solutions, in the working solutions after storage at $-70^{\circ} \mathrm{C}$ and in human and dog urine after storage at $-70^{\circ} \mathrm{C}$.

Stability experiments in the biomatrix were executed at 2 concentration levels for EO9 $(0.3$ and $40 \mu \mathrm{g} / \mathrm{mL})$, for EO5a $(0.6$ and $40 \mu \mathrm{g} / \mathrm{mL})$ and for $\mathrm{EO} 9-\mathrm{Cl}(0.3$ and $3.0 \mu \mathrm{g} / \mathrm{mL})$ in triplicate. The analytes were spiked separately to the biological matrix. EO9, EO5a and EO9-Cl are considered stable in the stock and working solutions when $90-110 \%$ of the fresh sample's ratio is found and they are considered stable in biological matrices or final solutions when $85-115 \%$ of the initial concentration is recovered.

\section{RESULTS AND DISCUSSION}

\subsection{Sample Pretreatment}

Liquid-liquid extraction (LLE) was investigated for the extraction of EO9, EO5a and $\mathrm{EO} 9-\mathrm{Cl}$ from urine, but the recoveries of EO9 were low and not reproducible (data not shown). To examine whether the recovery of EO9 could be increased more reproducibly with a direct injection, the urine samples were diluted with ammonium acetate $(\mathrm{pH} 8.5$; $0.1 \mathrm{M})$ - methanol $(7: 3, \mathrm{v} / \mathrm{v})$. This approach was indeed successful and interestingly, we also detected a new compound in the urine, which was identified as EO9-Cl.

Therefore, dilution of the urine samples was chosen as the sample pretreatment. The samples were diluted 10 times prior to analysis to ascertain that the final concentration would fit into the linear calibration range and to prevent contamination of the mass spectrometer with salts present in urine.

\subsection{Chromatography}

To our knowledge, no other assay has been described so far for the simultaneous determination of EO9, EO5a and EO9-Cl in human urine using HPLC coupled to the tandem MS. The chromatography was described earlier by us for determination of EO9 and EO5a in human plasma [16]. Representative chromatograms of EO9, EO5a and the internal standards at their LLOQ levels in stabilized human urine are depicted in Fig. (2). Peak shapes were excellent with the asymmetry factors of 1.0 for EO9, EO9-Cl and EO9-d3 and 1.2 for EO5a and EO5a-d4 and the capacity factors $\left(k^{\prime}\right)$ for all analytes of approximately 3 . Overall LC run time was only $6 \mathrm{~min}$.

\subsection{Mass Spectrometry}

In Fig. (3), Q1 mass spectrum EO9-Cl is presented. Apart from the protonated species at $\mathrm{m} / \mathrm{z} 325$ for EO9-Cl, sodium adducts are also observed at $\mathrm{m} / \mathrm{z} 347$, and the characteristic $\mathrm{Cl}$ isotope abundances are visible. Figs. (4-6), show MS/MS product ion scans (Q3 scan) of EO9, EO5a and EO9-Cl, respectively, across the range of $\mathrm{m} / \mathrm{z} 100-400$. An ion corresponding to the elimination of water $(\mathrm{m} / \mathrm{z} 271)$ from the molecular ion of EO9 was chosen for the parent mass transition 


\section{EO9}

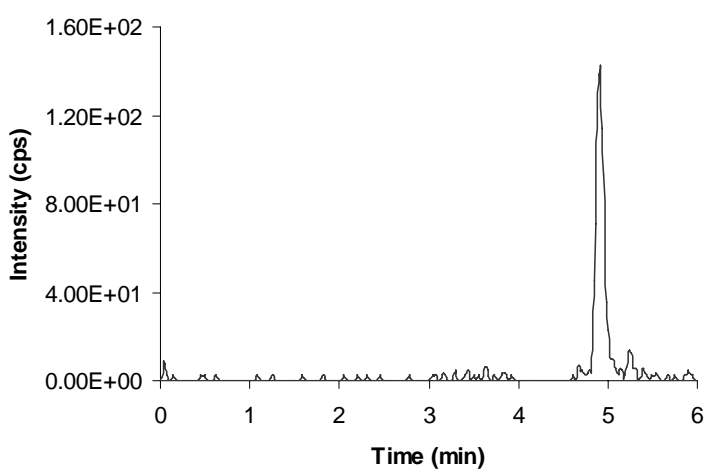

\section{EO5a}

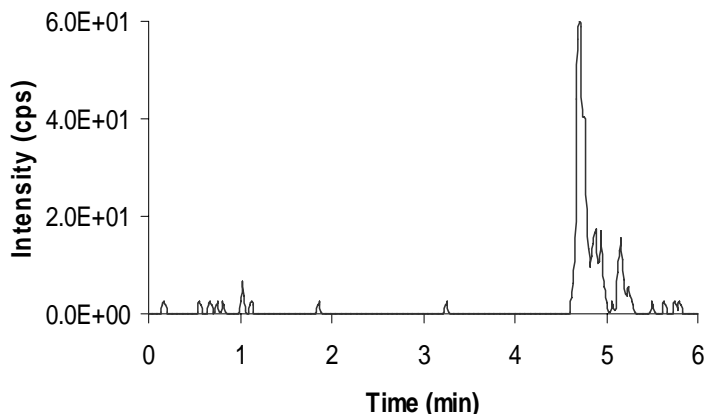

\section{EO9-d3}

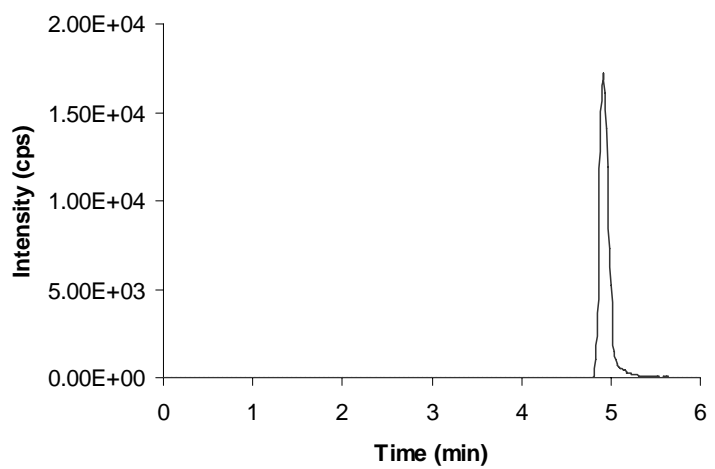

\section{E05a-d4}

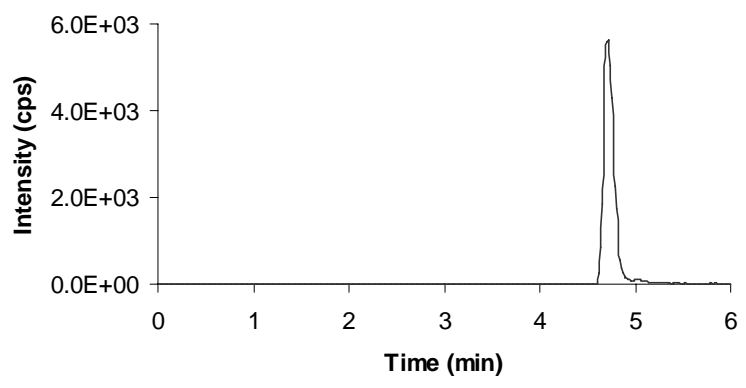

EO9-Cl

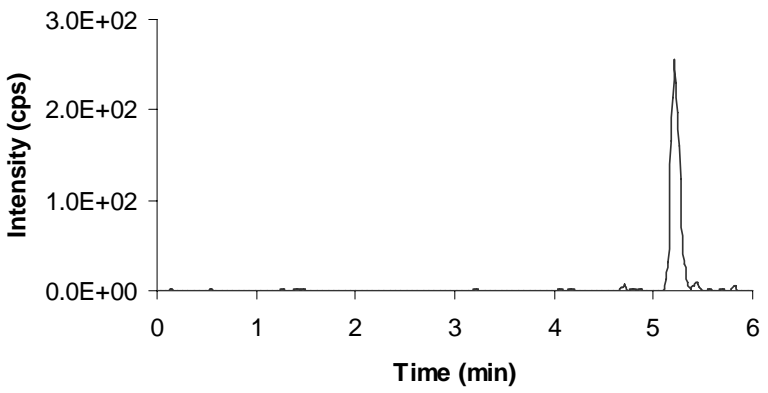

Fig. (2). Representative HPLC-MS/MS chromatograms of an LLOQ sample for EO9 (0.1 $\mu \mathrm{g} / \mathrm{mL}), \mathrm{EO} 9-\mathrm{d} 3$ (1,000 ng/mL), EO5a (0.2 $\mu \mathrm{g} / \mathrm{mL})$, EO5a-d4 $(1,000 \mathrm{ng} / \mathrm{mL})$ and EO9-Cl $(0.1 \mu \mathrm{g} / \mathrm{mL})$ from control human urine.

of EO9, because it was the most prominent, with its elimination occuring immediately in the ion source. The most abundant fragments observed in the fragmentation of the $\mathrm{m} / \mathrm{z}$ of 271 (EO9; Fig. 4), 307 (EO5a; Fig. 5) and 325 (EO9-Cl; Fig. 6) were product ions at $\mathrm{m} / \mathrm{z}$ of 241,231 and 241 , respectively, corresponding to the loss of the $\mathrm{CH}_{2} \mathrm{O}$ from the allylic alcohol $(\mathrm{m} / \mathrm{z} 241)$, the cleavage of the amine moiety and the elimination of water $(\mathrm{m} / \mathrm{z} 231)$ and the loss of the $\mathrm{CH}_{2} \mathrm{O}$ from the allylic alcohol and the elimination of the $\mathrm{Cl}$ atom $(\mathrm{m} / \mathrm{z}$ 241), respectively. As expected, no typical $\mathrm{Cl}$ pattern is seen at the $m / z$ of 241 . Consequently, multiple reaction monitoring (MRM) parameters were optimized on the $\mathrm{m} / \mathrm{z}$ of 271/241, 307/231 and 325/241 transitions for EO9, EO5a and EO9-Cl $[19,20]$. For EO9-d3 and EO5a-d4 similar transitions as for EO9 and EO5a, respectively, were selected and optimized.

\subsection{Validation}

\subsubsection{Linearity}

The assay was linear over a concentration range of 0.1 $\mu \mathrm{g} / \mathrm{mL}$ to $50 \mu \mathrm{g} / \mathrm{mL}$ for $\mathrm{EO} 9,0.2 \mu \mathrm{g} / \mathrm{mL}$ to $50 \mu \mathrm{g} / \mathrm{mL}$ for EO5a and $0.1 \mu \mathrm{g} / \mathrm{mL}$ to $4 \mu \mathrm{g} / \mathrm{mL}$ for $\mathrm{EO} 9-\mathrm{Cl}$ in stabilized human and $\operatorname{dog}$ urine. This range proved to be sufficient when measuring the samples from the (pre)-clinical studies with EO9. Interestingly, the linear range of EO9-Cl was much 


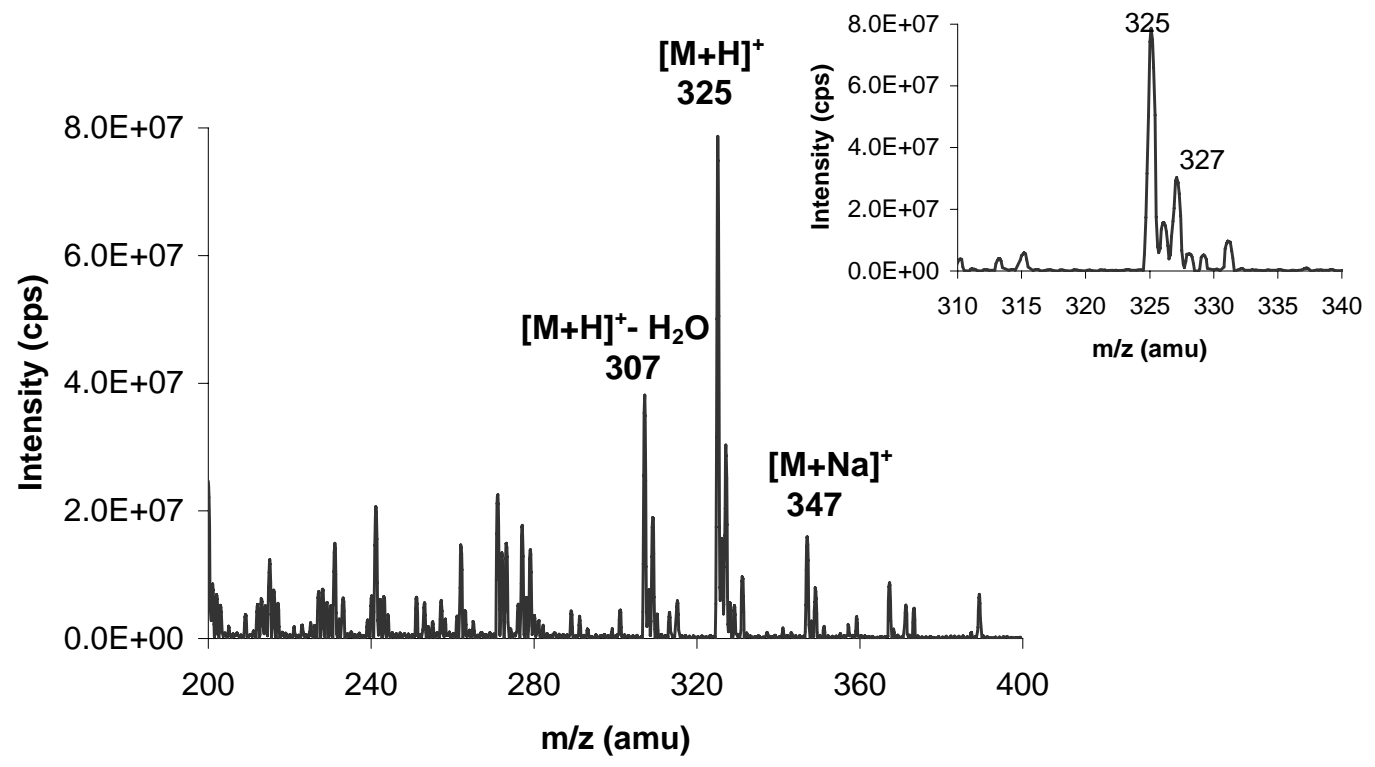

Fig. (3). Q1 ( $m / z, 200-400)$ mass spectrum of EO9-Cl.

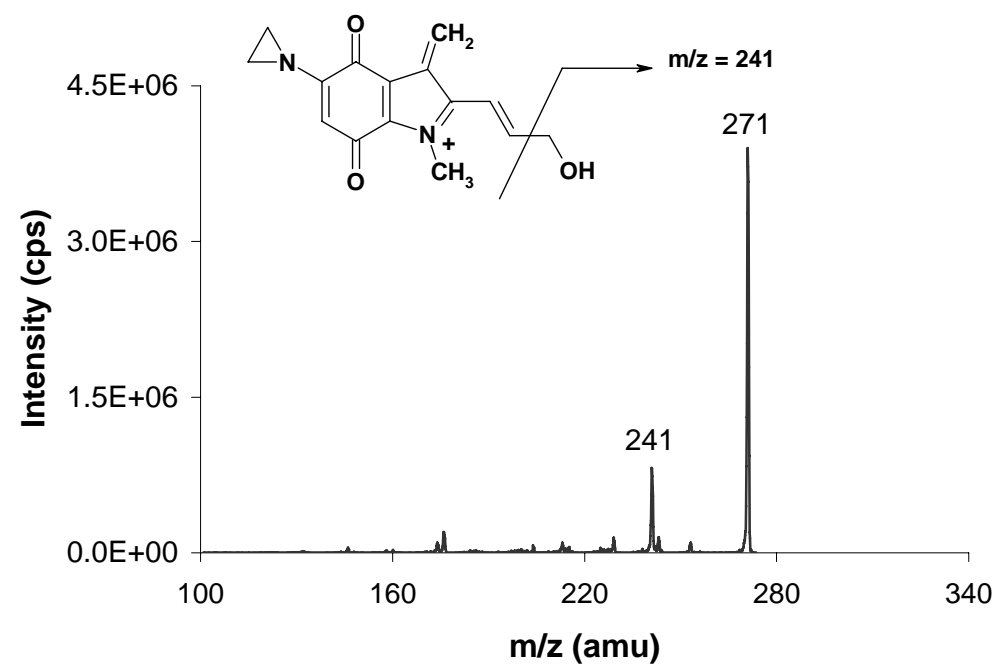

Fig. (4). MS/MS product ion scan of EO9 (precursor ion m/z 271).

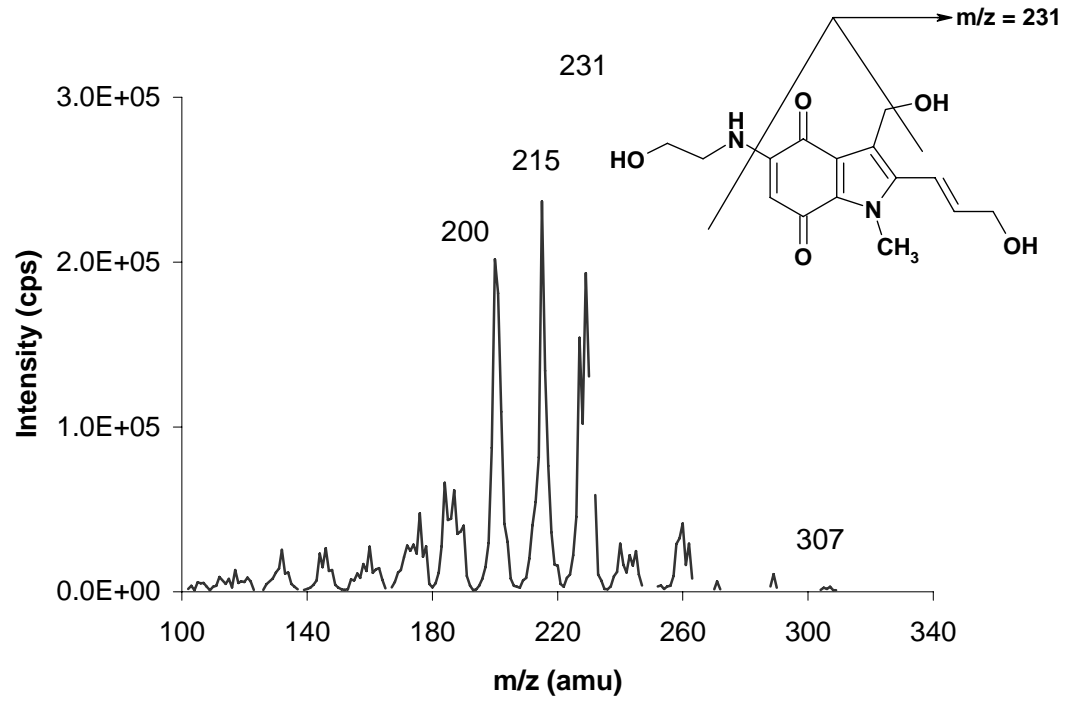

Fig. (5). MS/MS product ion scan of EO5a (precursor ion m/z 307). 


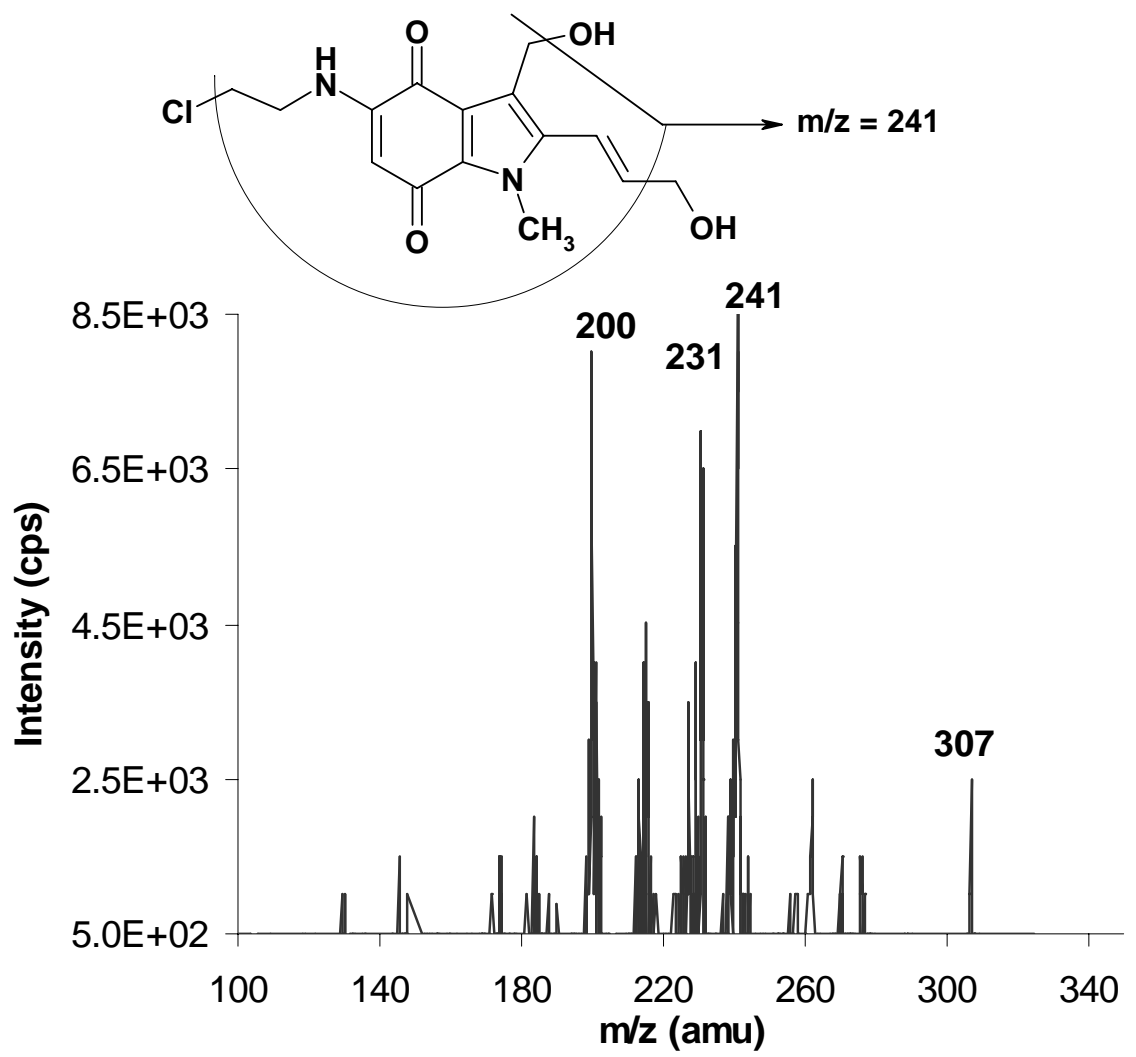

Fig. (6). MS/MS product ion scan of EO9-Cl (precursor ion $\mathrm{m} / \mathrm{z}, 325$ ).

smaller than for EO5a and EO9. This may be due to the different ionization properties of $\mathrm{EO} 9-\mathrm{Cl}$ compared to $\mathrm{EO} 9$ and EO5a.

Namely, it is believed that signal suppression occurs when matrix components compete with the analyte ions for access to the droplet surface for gas phase emission. This is described in a widely accepted model, proposed by Iribarne and Thomson [19], which explains the formation of gas phase ions by direct emission from the surface of highly charged spray droplets. Therefore, when contaminants, from samples processing or analyte extraction from physiological matrices, are ionized at the same time as the compound of interest (EO9-Cl), matrix signal ionization tend to occur, leading to the signal suppression of the analyte.

Another model, which may explain the limited linear range of $\mathrm{EO} 9-\mathrm{Cl}$, is based on the hypothesis that the ion evaporation rate from the droplet is proportional to the ion concentration in the droplet [21]. The basis of this model was the assumption that the Iribarne and Thomson (as described above) ion evaporation model was the principal mechanism for the ion transfer to the gas phase and involves the competition among ions for the limited number of excess charge sites on the generated droplet during ESI. This model was proposed and supported by the observations of Enke et al. [22], that at low concentrations of analyte, the response curves were linear and indifferent of other present low concentration analytes. However, at higher analyte concentrations, the response became independent of analyte concentration, but highly affected by the presence of other analytes $[23,24]$.
Because EO9-Cl has different chemical properties (less hydrophilic) than EO9 and EO5a, the above described models might contribute to the explanation of the non-linear behavior of EO9-Cl.

Using linear regression and $1 / \mathrm{x}^{2}$ weighing, the lowest total bias and the most constant bias across the range were obtained. Correlation coefficients of the calibration curves in human urine were better than 0.9945 for EO9, better than 0.9933 for EO5a and better than 0.9914 for EO9-Cl. Correlation coefficients of the calibration curve in dog urine were 0.9984 for EO9, 0.9974 for EO5a and 0.9948 for EO9-Cl. At all concentration levels, deviation of measured concentrations from nominal concentration were between $-8.9 \%$ and $6.8 \%$ with C.V. values less than $11.7 \%$ for human urine and between $-8.4 \%$ and $12.4 \%$ with C.V. values less than $16.3 \%$ for dog urine.

\subsubsection{Accuracy and Precision}

Assay performance (inter-assay accuracies and precisions) data for $\mathrm{EO} 9, \mathrm{EO} 5 \mathrm{a}$ and $\mathrm{EO} 9-\mathrm{Cl}$ is summarized in Table 1. The intra-assay accuracies (\% bias) in human urine were within $\pm 12.4 \%$ for EO9, within $\pm 10.7 \%$ for EO5a and within $\pm 13.6 \%$ for EO9-Cl for all concentrations and found to be acceptable (data not shown). The intra-assay precisions for EO9 in human urine were less than $7.79 \%$, for EO5a less than $12.8 \%$ and for EO9-Cl less than $5.42 \%$ for all concentrations and found to be acceptable. The intra-assay accuracies (\% bias) in dog urine were within $\pm 4.3 \%$ for EO9, within $\pm 9.0 \%$ for EO5a and within $\pm 9.0 \%$ for EO9-Cl for all concentrations and found to be acceptable (data not shown). The intra-assay precisions in dog urine for EO9 
were less than $7.62 \%$, for EO5a less than $10.6 \%$ and for EO9-Cl less than $12.7 \%$ for all concentrations and found to be acceptable. As defined by the lower and upper validation sample concentrations possessing acceptable accuracy and precision, the validated range for EO9, based on $20 \mu \mathrm{L}$ of stabilized human/dog urine is from $0.1 \mu \mathrm{g} / \mathrm{mL}$ to $50 \mu \mathrm{g} / \mathrm{mL}$, for EO5a is from $0.2 \mu \mathrm{g} / \mathrm{mL}$ to $50 \mu \mathrm{g} / \mathrm{mL}$ and for $\mathrm{EO} 9-\mathrm{Cl}$ is from $0.1 \mu \mathrm{g} / \mathrm{mL}$ to $4 \mu \mathrm{g} / \mathrm{mL}$, respectively.

\subsubsection{Limit of Detection}

The limit of detection is the concentration of EO9, EO5a and $\mathrm{EO} 9-\mathrm{Cl}$ in which the response of the analyte is 2 times higher than the response of the blank, and is established in three analytical runs in human urine. The mean LOD concentration is estimated at $6.7 \mathrm{ng} / \mathrm{mL}$ for $\mathrm{EO} 9,31.4 \mathrm{ng} / \mathrm{mL}$ for EO5a and $3.3 \mathrm{ng} / \mathrm{mL}$ for EO9-Cl.

\subsubsection{Specificity and Selectivity}

The MRM chromatograms of six batches of stabilized control drug-free human and dog urine contained no coeluting peaks $>20 \%$ of the EO9, EO5a and EO9-Cl area at the LLOQ level, and no co-eluting peaks $>5 \%$ of the area of internal standards. Deviations from the nominal concentrations at the LLOQ level in human urine were between -14.0 and $18.8 \%$ for EO9, between -18.5 and $3.8 \%$ for EO5a and between -19.6 and $-5.7 \%$ for $\mathrm{EO} 9-\mathrm{Cl}$ and found to be acceptable. Deviations from the nominal concentrations at the LLOQ level in dog urine were between -18.2 and $5.8 \%$ for EO9, between -4.3 and $10.9 \%$ for EO5a and between -18.2 and $-7.0 \%$ for $\mathrm{EO} 9-\mathrm{Cl}$ and found to be acceptable.

\subsubsection{Ion Suppression}

The mean ion-suppressions for EO9 and its internal standard EO9-d3 in human urine were $22.4 \pm 7.5 \%$ and

Table 1. Assay Performance Data for EO9, EO5a and EO9-Cl in Stabilized Human and Dog Urine

\begin{tabular}{|c|c|c|c|c|c|c|c|}
\hline Compound & $\begin{array}{l}\text { Matrix } \\
\text { (Urine) }\end{array}$ & $\begin{array}{c}\text { Nominal } \\
\text { Concentration } \\
(\mu \mathrm{g} / \mathrm{mL})\end{array}$ & $\begin{array}{c}\text { Measured } \\
\text { Concentration } \\
(\mu \mathrm{g} / \mathrm{mL})\end{array}$ & $\begin{array}{c}\text { Overall } \\
\text { Accuracy } \\
(\%)\end{array}$ & $\begin{array}{c}\text { Intra-Assay } \\
\text { Precision } \\
(\%)\end{array}$ & $\begin{array}{c}\text { Inter-Assay } \\
\text { Precision } \\
(\%)\end{array}$ & $\begin{array}{c}\text { Number } \\
\text { of } \\
\text { Replicates }\end{array}$ \\
\hline \multirow[t]{6}{*}{ EO9 } & human & 0.103 & 0.102 & 99.0 & 7.79 & 7.42 & 15 \\
\hline & human & 0.309 & 0.312 & 101 & 4.60 & 9.12 & 15 \\
\hline & human & 10.3 & 10.3 & 99.2 & 4.26 & 8.39 & 15 \\
\hline & $\operatorname{dog}$ & 0.103 & 0.101 & 97.8 & 7.62 & - & 5 \\
\hline & $\operatorname{dog}$ & 0.309 & 0.319 & 103 & 6.47 & - & 5 \\
\hline & $\operatorname{dog}$ & 10.3 & 10.7 & 104 & 2.84 & - & 5 \\
\hline \multirow{6}{*}{ EO5a } & human & 10.5 & 9.89 & 94.2 & 5.27 & 5.60 & 15 \\
\hline & human & 42.1 & 41.3 & 98.1 & 5.43 & 5.57 & 15 \\
\hline & $\operatorname{dog}$ & 0.211 & 0.201 & 95.1 & 9.07 & - & 5 \\
\hline & $\operatorname{dog}$ & 0.632 & 0.625 & 98.8 & 10.6 & - & 5 \\
\hline & $\operatorname{dog}$ & 10.5 & 10.3 & 98.3 & 3.99 & - & 5 \\
\hline & $\operatorname{dog}$ & 42.1 & 38.3 & 91.0 & 3.93 & - & 5 \\
\hline \multirow[t]{4}{*}{ EO9-Cl } & human & 0.101 & 0.105 & 104 & 4.91 & 7.83 & 15 \\
\hline & $\operatorname{dog}$ & 0.304 & 0.298 & 97.9 & 8.43 & - & 5 \\
\hline & $\operatorname{dog}$ & 2.02 & 2.05 & 102 & 10.4 & - & 5 \\
\hline & $\operatorname{dog}$ & 3.04 & 3.31 & 109 & 2.96 & - & 5 \\
\hline
\end{tabular}


$22.7 \pm 11.4 \%$, respectively. The mean ion-suppressions for EO5a and its internal standard EO5a-d4 were $29.3 \pm 4.9 \%$ and $30.0 \pm 9.5 \%$, respectively. The mean ion-suppression for EO9-Cl was $24.9 \pm 6.7 \%$. The ion-suppression was much higher in human urine in comparison to human plasma $( \pm$ $5 \%$ ). The high ion-suppression in urine is probably due to the salts present, which compete with the analytes for access to the droplet surface for gas phase emission.

\subsubsection{Carry-Over}

No responses in the first blank matrix at the retention times of EO9, EO5a and EO9-Cl were measured, indicating that no carry-over takes place.

\subsubsection{Stability}

The stability data for EO9, EO5a and EO9-Cl are summarized in Tables 2-4, respectively. EO9, EO5a and EO9-Cl are stable in blank formulation in human urine for up to 1 hour at an ice/water bath. EO9, EO5a and EO9-Cl are stable in human and dog urine for at least three freeze $\left(-70{ }^{\circ} \mathrm{C}\right) /$ thaw cycles, and are also stable in human and dog urine stored at nominally ambient temperatures for up to 6 hours. Furthermore, EO9, EO5a and EO9-Cl are stable up to 10 days in the final extract (from human urine) at ambient temperatures. Re-injection reproducibility was established and the analytical run can be re-injected after at least 24 hours of storage in the autosampler.

Table 2. Stability Data of EO9

\begin{tabular}{|c|c|c|c|c|c|c|c|}
\hline Compound & Conditions & Matrix & $\begin{array}{c}\text { Initial Conc. } \\
(\mu \mathrm{g} / \mathrm{mL})\end{array}$ & $\begin{array}{c}\text { Found Conc. } \\
\qquad(\mu \mathrm{g} / \mathrm{mL})\end{array}$ & $\begin{array}{l}\text { Dev. } \\
(\%)\end{array}$ & $\begin{array}{l}\text { C.V. } \\
(\%)\end{array}$ & $\begin{array}{c}\text { Number } \\
\text { of Replicates }\end{array}$ \\
\hline \multirow[t]{2}{*}{ EO9 } & ice/water batch, $1 \mathrm{~h}$ & Blank formulation - urine & 0.236 & 0.227 & -3.79 & 5.51 & 3 \\
\hline & & $(1: 2, \mathrm{v} / \mathrm{v})$ & 40.8 & 41.1 & 0.731 & 1.33 & 3 \\
\hline \multirow[t]{2}{*}{ EO9 } & 3 freeze $\left(-70^{\circ} \mathrm{C}\right) /$ thaw & human urine & 0.312 & 0.309 & -0.744 & 4.51 & 3 \\
\hline & cycles & & 39.8 & 36.1 & -9.16 & 3.74 & 3 \\
\hline \multirow[t]{2}{*}{ EO9 } & 3 freeze $\left(-70^{\circ} \mathrm{C}\right) /$ thaw & dog urine & 0.349 & 0.366 & 4.88 & 3.73 & 3 \\
\hline & cycles & & 43.2 & 40.0 & -7.54 & 0.250 & 3 \\
\hline \multirow[t]{2}{*}{ EO9 } & Ambient, $6 \mathrm{~h}$ & human urine & 0.312 & 0.296 & -4.99 & 2.35 & 3 \\
\hline & & & 39.8 & 40.1 & 0.666 & 5.09 & 3 \\
\hline \multirow[t]{2}{*}{ EO9 } & Ambient, $6 \mathrm{~h}$ & dog urine & 0.349 & 0.311 & -10.8 & 4.74 & 3 \\
\hline & & & 43.2 & 45.0 & 4.25 & 3.45 & 3 \\
\hline \multirow[t]{2}{*}{ EO9 } & $4^{\circ} \mathrm{C}, 15$ days & final extract & 0.312 & 0.301 & -3.61 & 11.1 & 3 \\
\hline & & & 39.8 & 38.4 & -3.58 & 0.259 & 3 \\
\hline \multirow[t]{3}{*}{ EO9 } & Autosampler, $10^{\circ} \mathrm{C}, 24 \mathrm{~h}$ & final extract (human urine) & 0.280 & 0.288 & 2.96 & 5.12 & 3 \\
\hline & & & 9.82 & 10.0 & 2.12 & 4.06 & 3 \\
\hline & & & 41.6 & 44.3 & 6.45 & 1.53 & 3 \\
\hline \multirow[t]{3}{*}{ EO9 } & Autosampler, $10^{\circ} \mathrm{C}, 24 \mathrm{~h}$ & final extract (dog urine) & 0.320 & 0.329 & 2.71 & 1.68 & 3 \\
\hline & & & 10.7 & 10.4 & -2.80 & 2.88 & 3 \\
\hline & & & 41.6 & 41.6 & 0.00 & 5.54 & 3 \\
\hline \multirow[t]{8}{*}{ EO9 } & $-20^{\circ} \mathrm{C}, 6$ months & working solutions in ethanol & 1.00 & 0.951 & -5.01 & 7.09 & 3 \\
\hline & & & 2.02 & 1.86 & -7.88 & 22.0 & 3 \\
\hline & & & 10.0 & 10.4 & 4.56 & 1.87 & 3 \\
\hline & & & 20.2 & 21.5 & 6.59 & 8.00 & 3 \\
\hline & & & 100 & 94.6 & -5.34 & 5.67 & 3 \\
\hline & & & 202 & 196 & -3.52 & 2.38 & 3 \\
\hline & & & 403 & 369 & -8.37 & 2.00 & 3 \\
\hline & & & 503 & 551 & 9.71 & 3.72 & 3 \\
\hline \multirow[t]{2}{*}{ EO9 } & $-70^{\circ} \mathrm{C}, 6$ months & stabilized human urine & 0.315 & 0.320 & 1.60 & 12.4 & 3 \\
\hline & & & 39.8 & 41.9 & 5.30 & 6.07 & 3 \\
\hline \multirow[t]{2}{*}{ EO9 } & $-70^{\circ} \mathrm{C}, 3$ months & stabilized dog urine & 0.349 & 0.319 & -8.60 & 19.6 & 3 \\
\hline & & & 43.2 & 44.4 & 2.93 & 5.61 & 3 \\
\hline
\end{tabular}


Table 3. Stability Data of EO5a

\begin{tabular}{|c|c|c|c|c|c|c|c|}
\hline Compound & Conditions & Matrix & $\begin{array}{c}\text { Initial Conc. } \\
\qquad(\mu \mathrm{g} / \mathrm{mL})\end{array}$ & $\begin{array}{c}\text { Found Conc. } \\
(\mu \mathrm{g} / \mathrm{mL})\end{array}$ & $\begin{array}{l}\text { Dev. } \\
(\%)\end{array}$ & $\begin{array}{l}\text { C.V. } \\
(\%)\end{array}$ & $\begin{array}{c}\text { Number } \\
\text { of Replicates }\end{array}$ \\
\hline EO5a & ice/water batch, $1 \mathrm{~h}$ & $\begin{array}{l}\text { Blank formulation - urine } \\
\qquad(1: 2, \mathrm{v} / \mathrm{v})\end{array}$ & $\begin{array}{l}0.603 \\
40.4\end{array}$ & $\begin{array}{l}0.581 \\
39.1\end{array}$ & $\begin{array}{l}-3.65 \\
-3.22\end{array}$ & $\begin{array}{l}10.8 \\
7.13\end{array}$ & $\begin{array}{l}3 \\
3\end{array}$ \\
\hline EO5a & $\begin{array}{c}3 \text { freeze }\left(-70^{\circ} \mathrm{C}\right) / \text { thaw } \\
\text { cycles }\end{array}$ & human urine & $\begin{array}{c}0.600 \\
38.9\end{array}$ & $\begin{array}{c}0.602 \\
37.0\end{array}$ & $\begin{array}{l}0.333 \\
-4.80\end{array}$ & $\begin{array}{l}7.26 \\
3.32\end{array}$ & $\begin{array}{l}3 \\
3\end{array}$ \\
\hline EO5a & $\begin{array}{c}3 \text { freeze }\left(-70^{\circ} \mathrm{C}\right) / \text { thaw } \\
\text { cycles }\end{array}$ & dog urine & $\begin{array}{c}0.611 \\
39.1\end{array}$ & $\begin{array}{c}0.589 \\
39.5\end{array}$ & $\begin{array}{l}-3.65 \\
1.02\end{array}$ & $\begin{array}{l}10.5 \\
2.16\end{array}$ & $\begin{array}{l}3 \\
3\end{array}$ \\
\hline EO5a & Ambient, 6h & human urine & $\begin{array}{c}0.600 \\
38.9\end{array}$ & $\begin{array}{c}0.593 \\
37.7\end{array}$ & $\begin{array}{l}-1.11 \\
-2.92\end{array}$ & $\begin{array}{l}9.02 \\
3.77\end{array}$ & $\begin{array}{l}3 \\
3\end{array}$ \\
\hline EO5a & Ambient, $6 \mathrm{~h}$ & dog urine & $\begin{array}{c}0.611 \\
39.1\end{array}$ & $\begin{array}{c}0.601 \\
41\end{array}$ & $\begin{array}{r}-1.64 \\
4.86\end{array}$ & $\begin{array}{l}4.52 \\
6.88\end{array}$ & $\begin{array}{l}3 \\
3\end{array}$ \\
\hline EO5a & $4^{\circ} \mathrm{C}, 15$ days & final extract & $\begin{array}{l}0.600 \\
38.9\end{array}$ & $\begin{array}{c}0.566 \\
36.8\end{array}$ & $\begin{array}{l}-5.67 \\
-5.32\end{array}$ & $\begin{array}{l}3.93 \\
3.55\end{array}$ & $\begin{array}{l}3 \\
3\end{array}$ \\
\hline EO5a & Autosampler, $10^{\circ} \mathrm{C}, 24 \mathrm{~h}$ & final extract (human urine) & $\begin{array}{l}0.591 \\
9.76 \\
38.8\end{array}$ & $\begin{array}{l}0.652 \\
10.2 \\
40.4\end{array}$ & $\begin{array}{l}10.2 \\
4.17 \\
4.21\end{array}$ & $\begin{array}{l}6.39 \\
8.31 \\
5.85\end{array}$ & $\begin{array}{l}3 \\
3 \\
3\end{array}$ \\
\hline EO5a & Autosampler, $10^{\circ} \mathrm{C}, 24 \mathrm{~h}$ & final extract (dog urine) & $\begin{array}{r}0.619 \\
10.4 \\
39.0\end{array}$ & $\begin{array}{c}0.653 \\
9.80 \\
38.9\end{array}$ & $\begin{array}{r}5.44 \\
-5.50 \\
-0.342\end{array}$ & $\begin{array}{l}1.53 \\
6.62 \\
1.71\end{array}$ & $\begin{array}{l}3 \\
3 \\
3\end{array}$ \\
\hline EO5a & $-20^{\circ} \mathrm{C}, 6$ months & working solutions in ethanol & $\begin{array}{l}2.04 \\
5.10 \\
10.2 \\
20.4 \\
102 \\
204 \\
408 \\
510\end{array}$ & $\begin{array}{l}2.05 \\
4.77 \\
9.85 \\
20.5 \\
101 \\
197 \\
388 \\
518\end{array}$ & $\begin{array}{c}0.404 \\
-6.46 \\
-3.52 \\
0.290 \\
-1.02 \\
-3.33 \\
-4.65 \\
1.69\end{array}$ & $\begin{array}{l}7.35 \\
11.7 \\
5.73 \\
11.9 \\
7.29 \\
8.02 \\
2.07 \\
6.48\end{array}$ & $\begin{array}{l}3 \\
3 \\
3 \\
3 \\
3 \\
3 \\
3 \\
3\end{array}$ \\
\hline EO5a & $-70^{\circ} \mathrm{C}, 6$ months & stabilized human urine & $\begin{array}{c}0.600 \\
38.9\end{array}$ & $\begin{array}{c}0.612 \\
39.3\end{array}$ & $\begin{array}{l}2.00 \\
1.03\end{array}$ & $\begin{array}{l}15.1 \\
7.36\end{array}$ & $\begin{array}{l}3 \\
3\end{array}$ \\
\hline EO5a & $-70^{\circ} \mathrm{C}, 3$ months & stabilized dog urine & $\begin{array}{c}0.611 \\
39.1\end{array}$ & $\begin{array}{c}0.592 \\
41.0\end{array}$ & $\begin{array}{l}-3.22 \\
4.86\end{array}$ & $\begin{array}{l}3.13 \\
4.03\end{array}$ & $\begin{array}{l}3 \\
3\end{array}$ \\
\hline
\end{tabular}

Notes: C.V. = coefficient of variation; Dev = deviation from time zero.

Finally, EO9, EO5a and EO9-Cl are stable in the stock solutions for up to 6 months of storage at $-20^{\circ} \mathrm{C}$ [16]. $\mathrm{EO} 9$, $\mathrm{EO} 5 \mathrm{a}$ and $\mathrm{EO} 9-\mathrm{Cl}$ are stable in the working solutions in ethanol and in the stabilized human urine for up to 6 months and in the stabilized dog urine for up to 3 months at nominally $-70^{\circ} \mathrm{C}$.

\section{CONCLUSIONS}

An accurate, simple, reproducible, and selective LCMS/MS assay has been developed for the quantification of EO9 and its conversion products EO5a and EO9-Cl in human and dog urine. Using $20 \mu \mathrm{L}$ stabilized human and dog urine aliquots, the assay quantifies a range of $0.1 \mu \mathrm{g} / \mathrm{mL}$ to $50 \mu \mathrm{g} / \mathrm{mL}$ for EO9, $0.2 \mu \mathrm{g} / \mathrm{mL}$ to $50 \mu \mathrm{g} / \mathrm{mL}$ for EO5a, and of
$0.1 \mu \mathrm{g} / \mathrm{mL}$ to $4 \mu \mathrm{g} / \mathrm{mL}$ for EO9-Cl. Validation results demonstrate that the $\mathrm{EO} 9, \mathrm{EO} 5 \mathrm{a}$ and $\mathrm{EO} 9-\mathrm{Cl}$ concentrations can be accurately and precisely quantified in human and dog urine. This assay is used to support (pre)-clinical pharmacologic studies with EO9.

\section{ABBREVIATIONS}

API $=$ Atmospheric pressure ionisation

$\mathrm{CE} \quad=\quad$ Collision energy

C.V. $=$ Coefficient of variation

DEV $=$ Deviation from time zero

DP $=$ Declustering potential 
Table 4. Stability Data of EO9-Cl

\begin{tabular}{|c|c|c|c|c|c|c|c|}
\hline Compound & Conditions & Matrix & $\begin{array}{c}\text { Initial Conc. } \\
\quad(\mu \mathrm{g} / \mathrm{mL})\end{array}$ & $\begin{array}{c}\text { Found Conc. } \\
\qquad(\mu \mathrm{g} / \mathrm{mL})\end{array}$ & $\begin{array}{l}\text { Dev. } \\
(\%)\end{array}$ & $\begin{array}{l}\text { C.V. } \\
(\%)\end{array}$ & $\begin{array}{c}\text { Number } \\
\text { of Replicates }\end{array}$ \\
\hline \multirow[t]{2}{*}{$\mathrm{EO} 9-\mathrm{Cl}$} & Ice/water batch, $1 \mathrm{~h}$ & Blank formulation - urine & 0.293 & 0.304 & 3.76 & 4.76 & 3 \\
\hline & & $(1: 2, \mathrm{v} / \mathrm{v})$ & 2.59 & 2.69 & 3.73 & 3.36 & 3 \\
\hline \multirow[t]{2}{*}{$\mathrm{EO} 9-\mathrm{Cl}$} & 3 freeze $\left(-70^{\circ} \mathrm{C}\right) /$ thaw & human urine & 0.305 & 0.275 & -9.85 & 6.52 & 3 \\
\hline & cycles & & 2.84 & 2.61 & -8.09 & 2.24 & 3 \\
\hline \multirow[t]{2}{*}{$\mathrm{EO} 9-\mathrm{Cl}$} & 3 freeze $\left(-70^{\circ} \mathrm{C}\right) /$ thaw & dog urine & 0.328 & 0.362 & 10.3 & 3.61 & 3 \\
\hline & cycles & & 2.67 & 2.78 & 4.38 & 4.98 & 3 \\
\hline \multirow[t]{2}{*}{$\mathrm{EO} 9-\mathrm{Cl}$} & Ambient, $6 \mathrm{~h}$ & human urine & 0.305 & 0.275 & -9.74 & 2.62 & 3 \\
\hline & & & 2.84 & 2.63 & -7.50 & 5.93 & 3 \\
\hline \multirow[t]{2}{*}{$\mathrm{EO} 9-\mathrm{Cl}$} & Ambient, $6 \mathrm{~h}$ & dog urine & 0.328 & 0.287 & -12.6 & 11.5 & 3 \\
\hline & & & 2.67 & 2.69 & 0.875 & 6.72 & 3 \\
\hline \multirow[t]{2}{*}{$\mathrm{EO} 9-\mathrm{Cl}$} & $4^{\circ} \mathrm{C}, 10$ days & final extract & 0.305 & 0.329 & 7.88 & 0.63 & 3 \\
\hline & & & 2.84 & 3.16 & 11.1 & 4.66 & 3 \\
\hline \multirow[t]{3}{*}{$\mathrm{EO} 9-\mathrm{Cl}$} & Autosampler, $10^{\circ} \mathrm{C}, 24 \mathrm{~h}$ & final extract (human urine) & 0.297 & 0.274 & -7.64 & 0.73 & 3 \\
\hline & & & 2.06 & 1.99 & -3.55 & 4.52 & 3 \\
\hline & & & 3.31 & 3.38 & 2.01 & 2.52 & 3 \\
\hline \multirow[t]{3}{*}{$\mathrm{EO} 9-\mathrm{Cl}$} & Autosampler, $10^{\circ} \mathrm{C}, 24 \mathrm{~h}$ & final extract (dog urine) & 0.302 & 0.309 & 2.32 & 3.79 & 3 \\
\hline & & & 2.00 & 2.19 & 9.68 & 8.03 & 3 \\
\hline & & & 3.27 & 3.12 & -4.69 & 9.05 & 3 \\
\hline $\mathrm{EO} 9-\mathrm{Cl}$ & $-20^{\circ} \mathrm{C}, 6$ months & stock solution in ethanol & 1000 & 956 & -4.44 & 11.1 & 3 \\
\hline \multirow[t]{4}{*}{$\mathrm{EO} 9-\mathrm{Cl}$} & $-20^{\circ} \mathrm{C}, 6$ months & $\begin{array}{l}\text { working solutions in etha- } \\
\text { nol }\end{array}$ & 2.00 & 1.91 & -4.64 & 6.73 & 3 \\
\hline & & & 10.0 & 9.20 & -8.00 & 1.56 & 3 \\
\hline & & & 20.0 & 21.1 & 5.57 & 3.89 & 3 \\
\hline & & & 30.0 & 27.4 & -8.67 & 4.33 & 3 \\
\hline \multirow[t]{2}{*}{$\mathrm{EO} 9-\mathrm{Cl}$} & $-70^{\circ} \mathrm{C}, 6$ months & stabilized human urine & 0.305 & 0.260 & -14.7 & 3.81 & 3 \\
\hline & & & 2.84 & 2.83 & -0.362 & 4.77 & 3 \\
\hline \multirow[t]{2}{*}{$\mathrm{EO} 9-\mathrm{Cl}$} & $-70^{\circ} \mathrm{C}, 3$ months & stabilized dog urine & 0.328 & 0.324 & -1.32 & 14.9 & 3 \\
\hline & & & 2.67 & 2.58 & -3.25 & 2.54 & 3 \\
\hline
\end{tabular}

EDTA $=$ Ethylenediaminetetraacetic acid

ESI = Electrospray ionisation

FDA $=$ Food and Drug Administration

$\mathrm{FP} \quad=$ Focusing potential

LLOQ = Lower limit of quantitation

LOD $=$ Limit of detection

MRM = Multiple reaction monitoring

SD $=$ Standard deviation

SWFI = Sterile water for injection

TRIS = Tris(hydroxymethyl)aminomethane

ULOQ = Upper limit of quantitation

\section{REFERENCES}

[1] Hendriks, H.R.; Pizao, P.E.; Berger, D.P.; Kooistra, K.L.; Bibby, M.C.; Boven, E.; Dreef-van der Meulen, H.C.; Henrar, R.E.; Fiebig, H.H.; Double, J.A. EO9: a novel bioreductive alkylating indoloquinone with preferential solid tumour activity and lack of bone marrow toxicity in preclinical models. Eur. J. Cancer, 1993, 29A, 897-906.

[2] Smitskamp-Wilms, E.; Hendriks, H.R.; Peters, G.J. Development, pharmacology, role of DT-diaphorase and prospects of the indoloquinone EO9. Gen. Pharmacol., 1996, 27, 421-429.

[3] Phillips, R.M.; Jaffar, M.; Maitland, D.J.; Loadman, P.M.; Shnyder, S.D.; Steans, G.; Cooper, P.A.; Race, A.; Patterson, A.V.; Stratford, I.J. Pharmacological and biological evaluation of a series of substituted 1,4-naphthoquinone bioreductive drugs. Biochem. Pharmacol., 2004, 68, 2107-2116.

[4] McLeod, H.L.; Graham, M.A.; Aamdal, S.; Setanoians, A.; Groot, Y.; Lund, B. Phase I pharmacokinetics and limited sampling strategies for the bioreductive alkylating drug EO9. EORTC Early Clinical Trials Group. Eur. J. Cancer, 1996, 32A, 1518-1522. 
[5] Cummings, J.; Spanswick, V.J.; Gardiner. J.; Ritchie. A.; Smyth, J.F. Pharmacological and biochemical determinants of the antitumour activity of the indoloquinone EO9. Biochem. Pharmacol., 1998, 55, 253-260.

[6] Stratford, I.J.; Workman, P. Bioreductive drugs into the next millennium. Anticancer Drug Des., 1998, 13, 519-528.

[7] Jonkman-de Vries, J.D.; Winkelhorst, J.; Underberg, W.J.M.; Henrar, R.E.C.; Beijnen, J.H. A systematic study on the chemical stability of the novel indoloquinone antitumor agent EO9. Int. J. Pharm., 1993, 100, 181-186.

[8] Workman, P.; Stratford, I.J. The experimental development of bioreductive drugs and their role in cancer therapy. Cancer Metastasis Rev., 1993, 12, 73-82.

[9] Vainchtein, L.D.; Rosing, H.; Mirejovsky, D.; Lenaz, L.; Schellens, J.H.; Beijnen, J.H. Stability experiments in human urine with EO9 (apaziquone): a novel anticancer agent for the intravesical treatment of bladder cancer. J. Pharm. Biomed. Anal., 2007, 43, 285-292.

[10] Schellens, J.H.; Planting, A.S.; van Acker, B.A.; Loos, W.J.; de Boer-Dennert, M.; Van der Burg, M.E.; Koier, I.; Krediet, R.T.; Stoter, G.; Verweij, J. Phase I and pharmacologic study of the novel indoloquinone bioreductive alkylating cytotoxic drug E09. $J$. Natl. Cancer Inst., 1994, 86, 906-912.

[11] Phillips, R.M.; Loadman, P.M.; Cronin, B.P. Evaluation of a novel in vitro assay for assessing drug penetration into avascular regions of tumours. Br. J. Cancer, 1998, 77, 2112-2119.

[12] Choudry, G.A.; Stewart, P.A.; Double, J.A.; Krul, M.R.; Naylor, B.; Flannigan, G.M.; Shah, T.K.; Brown, J.E.; Phillips, R.M. A novel strategy for NQO1 (NAD(P)H:quinone oxidoreductase, EC 1.6.99.2) mediated therapy of bladder cancer based on the pharmacological properties of EO9. Br. J. Cancer, 2001, 85, 1137-1146.

[13] Puri, R.; Palit, V.; Loadman, P.M.; Flannigan, M.; Shah, T.; Choudry, G.A.; Basu, S.; Double, J.A.; Lenaz, G.; Chawla, S.; Beer, M.; Van Kalken, C.; de Boer, R.; Beijnen, J.H.; Twelves, C.J.; Phillips, R.M. Phase I/II pilot study of intravesical apaziquone (EO9) for superficial bladder cancer. J. Urol., 2006, 176, 1344-1348.

[14] Van der Heijden, A.G.; Moonen, P.M.; Cornel, E.B.; Vergunst, H.; De Reijke, T.M.; Van Boven, E.;Barten, E.J.; Puri, R.; van Kalken, C.K.; Witjes, J.A. Phase II marker lesion study with intravesical in- stillation of apaziquone for superficial bladder cancer: toxicity and marker response. J. Urol., 2006, 176, 1349-1353.

[15] Schellens, J.H.; Loos, W.; Beijnen, J.H.; Stoter, G.; Verweij, J. Sensitive isocratic high-performance liquid chromatographic determination of a novel indoloquinone cytotoxic drug (EO9) in human plasma and urine. J. Chromatogr., 1993, 615, 309-315.

[16] Vainchtein, L.D.; Rosing, H.; Mirejovsky, D.; Huynh, V.; Lenaz, L.; Hillebrand, M.J.; Schellens, J.H.; Beijnen, J.H. Quantitative analysis of EO9 (apaziquone) and its metabolite EO5a in human plasma by high-performance liquid chromatography under basic conditions coupled to electrospray tandem mass spectrometry. $J$. Mass Spectrom., 2006, 41, 1268-1276.

[17] U.S. Food and Drug Administration: Centre for Drug Evaluation and Research: Guidance for Industry. Bioanalytical Method Validation. http://www.fda. gov/cder/quidance/4252fnl.htm 2001 (accessed February 10, 2008)

[18] Rosing, H.; Man, W.; Doyle, E.; Bult, A.; Beijnen, J.H. Bioanalytical liquid chromatographic method validation: a review of current practices and procedures. J. Liq. Chromatogr. Relat. Technol., 2000, 23, 329-341.

[19] Thomson, B.A.; Iribarne, J.V. Field induced ion evaporation from liquid surfaces at atmospheric pressure. J. Chem. Phys., 1979, 71 , 4451-4453.

[20] Choi, B.K.; Hercules, D.M.; Gusev, A.I. LC-MS/MS signal suppression effects in the analysis of pesticides in complex environmental matrices. Anal. Chem., 2001, 369, 370-374.

[21] Tang, L.; Kebarle, P. Effect on the conductivity of the electrosprayed solution on the electrospray current: factors determining analyte sensitivity on electrospray mass spectrometry. Anal. Chem., 1991, 63, 2709-2712.

[22] Enke, C.G. A predictive model for matrix and analyte effects in electrospray ionization of singly-charged ionic analytes. Anal. Chem., 1997, 69, 4885-4888.

[23] Cech, N.B.; Enke, C.G. Effect of affinity for droplet surfaces on the fraction of analyte molecules charged during electrospray droplet fission. Anal. Chem., 2001, 73, 4632-4636.

[24] Constantopoulos, T.L.; Jackson, G.S.E.C.G. Effects of salt concentration on analyte response using electrospray ionization mass spectrometry. J. Am. Chem. Soc. Mass Spectrom., 1999, 10, 625-630.

(C) Vainchtein et al.; Licensee Bentham Open.

This is an open access article licensed under the terms of the Creative Commons Attribution Non-Commercial License (http://creativecommons.org/licenses/by$\mathrm{nc} / 3.0 /$ ) which permits unrestricted, non-commercial use, distribution and reproduction in any medium, provided the work is properly cited. 